\title{
WITHDRAWN: THE EFFECT OF CAPACITY CONSTRAINT ON PRICING DECISION AND COORDINATION CONTRACT IN RECYCLING CHANNELS
}

\author{
LANG XU* AND JIA SHI
}

\begin{abstract}
This article has been withdrawn at the request of the authors, who did not approve the publication in a supplementary issue. Furthermore, the authors wish to make some amendments to the data and model.
\end{abstract}

Received February 2, 2019. Accepted May 17, 2020.

College of Transport and Communications, Shanghai Maritime University, Shanghai, P.R. China.

*Corresponding author: jerry_langxu@yeah. net 